ORIGINAL

\title{
Nutrient absorption in lambs fed diets containing different amounts of phosphorus
}

\author{
Absorción de nutrientes en corderos alimentados con dietas con \\ diferentes cantidades de fósforo
}

\author{
René Patiño $\mathrm{P}^{1{ }^{*}}$ Ph.D, Tanimara Soares da Silva, ${ }^{2}$ M.Sc, José C. da Silva Filho, ${ }^{3}$ Ph.D, \\ Mohamed Emad Nasser, ${ }^{4}$ Ph.D, Dorinha Smith Vitti, ${ }^{2}$ Ph.D, José A. Moreira, ${ }^{5}$ Ph.D.
}

\begin{abstract}
${ }^{1}$ Universidad de Sucre, Sincelejo, Colombia. Cr. 28 5-267. ${ }^{2}$ Centro de Energia Nuclear na Agricultura, CENA/USP. Piracicaba, SP. Brasil. CEP 13400-970. 'Universidade Federal de Lavras, UFLA. Lavras, MG. Brasil. CEP 27300-000. ${ }^{4}$ Alexandria University, Alexandria, Egipt. ${ }^{5}$ Universidade Federal do Rio Grande do Norte. Natal, Brasil. *Correspondencia: rene.patino@unisucre.edu.co
\end{abstract}

Recibido: Octubre de 2011; Aceptado: Junio de 2012.

\begin{abstract}
Objective. Evaluate the effect of increasing $P$ intake on nutrient digestibility, and compare the true and apparent absorption coefficients of $\mathrm{P}$ and $\mathrm{Ca}$ in lambs. Materials and methods. Twenty-four Santa Ines sheep, with an average weight of $33.6 \pm 1.6 \mathrm{~kg}$, were distributed into four treatments $(0$, 2,4 and $6 \mathrm{~g} /$ day of supplementary P) with forage: concentrate ratio of 70:30. The study of apparent nutrient digestibility was conducted during the first week, using the total feces collection method. During the second week, after injection of $7.4 \mathrm{MBq}$ of ${ }^{32} \mathrm{P}$ and $7.7 \mathrm{MBq}$ of ${ }^{45} \mathrm{Ca}$, apparent (AAC) and true (TAC) absorption coefficients of $P$ and $C a$ were determined. The lambs were kept in metabolic cages. Results. The increase in $P$ intake did not affect $(p>0.05)$ dry matter, crude protein, NDF or ADF digestibility, but the TAC of $P$ and $\mathrm{Ca}$ and mineral matter digestibility decreased. The AAC was not affected $(p=0.10)$. A cubic relationship was observed between $P$ intake and TAC (TAC $\left.=2.16-1.95 X+0.55 X^{2}-0.04 X^{3} ; R^{2}=0.38\right)$ and linear relationship with the TAC of $C a\left(T A C=0.559-0.03 X ; R^{2}=0.26\right)$. TAC and AAC values were different $(p<0.001)$. Conclusions. The increase in P intake doesn't impact organic matter digestibility, but does affect $\mathrm{P}$ and $\mathrm{Ca}$ absorption. Apparent digestibility is not a reliable parameter to determine the efficiency of $\mathrm{P}$ and $\mathrm{Ca}$ absorption.
\end{abstract}

Key words: Absorption, calcium, phosphorus, radioisotopes, ruminants (Source: DeCS).

\section{RESUMEN}

Objetivo. Evaluar el efecto del incremento en la ingestión de P sobre la digestibilidad de los nutrientes, y comparar los coeficientes de digestibilidad real y aparente de Ca y $\mathrm{P}$ en ovinos. Materiales y métodos. Veinticuatro ovinos de la raza Santa Inés, con $33.6 \pm 1.6 \mathrm{~kg}$ de peso, fueron asignados a cuatro tratamientos $(0,2,4$ y $6 \mathrm{~g} /$ día de $\mathrm{P}$ suplementario) con relación forraje:concentrado de 70:30. El estudio de digestibilidad aparente de los nutrientes se realizó la primera semana usando el método de colecta total de heces. La segunda semana, luego de inyectar $7.4 \mathrm{MBq}$ de ${ }^{32} \mathrm{P}$ y 7.7 $\mathrm{MBq}$ de ${ }^{45} \mathrm{Ca}$, se realizó el estudio de absorción real (CAV) y aparente (AAC), en jaulas de estudio de metabolismo. Resultados. El incremento en la ingestión de P no afectó $(p>0.05)$ la digestibilidad 
aparente de la materia seca, proteína bruta, FDN o FDA. EI CAV de Ca y de P y la digestibilidad de la materia mineral presentaron una reducción. EL AAC no fue afectado $(p=0.10)$. La ecuación $C A V=2.16-1.95 X+0.55 X^{2}-0.04 X^{3}\left(R^{2}=0.38\right)$ explicó la relación entre el CAV de $P$ y el incremento en su ingestión, y la ecuación TAC $=0.559-0.03 X\left(R^{2}=0.26\right)$, la relación entre el CAV de Ca y la ingestión de $P$. Los valores de AAC y CAV difirieron entre sí $(p<0.001)$. Conclusiones. La ingestión de $\mathrm{P}$ no afectó la digestibilidad de la fracción orgánica del alimento, pero sí la absorción de $\mathrm{P}$ y $\mathrm{Ca}$. El coeficiente de absorción aparente no fue un parámetro confiable para determinar la eficiencia de absorción de $\mathrm{P}$ y Ca.

Palabras clave: Absorción, calcio, fósforo, radioisótopos, rumiantes (Fuente: DeCS).

\section{INTRODUCTION}

Due to the polluting potential of $P$ present in animal feces, many aspects related to the manipulation of dietary phosphates have been tested to define strategies for reducing mineral loss of the environment without negatively affecting animal performance.

In ruminants, the amount of $\mathrm{P}$ excreted depends on the amount ingested, the P source, and other factors inherent to the individual, such as the species and physiological stage (1).

The most widely used measurement to determine the efficiency in which a nutrient is absorbed in the gastrointestinal tract is the absorption coefficient, both true and apparent. In ruminants, for some nutritional components of the diet (NDF, ADF), the apparent digestibility coefficient is commonly used, and represents a reliable measure (2). However, for other components $(\mathrm{N}, \mathrm{P}, \mathrm{Ca})$ this measurement is not the most appropriate for aspects that characterize the physiology and pattern of the endogenous forms of these elements, as happens with $P$ (3). One of the most critical factors which cause controversy regarding the dietary requirement of $P$ in ruminants is the variability of the coefficient of absorption (4). However, the coefficient of apparent absorption is considered when studying or analyzing the efficiency of absorption of that the dietary $\mathrm{P}(5)$.

There are only a few published studies $(2,5)$ that evaluate the effect of increasing the $P$ intake on the digestibility of other nutrients in the diet and even fewer comparisons, within the same study, of the coefficients of real and apparent absorption of $P$ when increasing intake of the mineral.

This research was conducted to characterize the relationship between the coefficients of real and apparent absorption of $\mathrm{Ca}$ and $\mathrm{P}$, and to assess the effect of the increase in $\mathrm{P}$ intake on the digestibility of dietary components in growing sheep.

\section{MATERIALS AND METHODS}

Local. The experiment was conducted at the Laboratório de Nutrição Animal (Laboratory of Animal Nutrition) of the Centro de Energia Nuclear na Agricultura (Center for Nuclear Energy and Agriculture) (CENA), at the Universidade de São Paulo $\left(22^{\circ} 42^{\prime} 47.24^{\prime \prime}\right.$ S and 47037'53.97'N), in Piracicaba city, Brazil.

Animals. Twenty-four male Santa Ines sheep, eight months old and $33.6 \mathrm{~kg}( \pm 1.6) \mathrm{BW}$ were used. The experiment was conducted in two stages. Initially, animals were kept in group pens, divided by treatments, for the adaptation period to the experimental diets during seven days. They were later transferred to metabolism cages, equipped with feces and urine collectors, feeders and drinkers, for two weeks. The study of apparent digestibility of nutrients was conducted during the first week in cages, except for $\mathrm{Ca}$ and $\mathrm{P}$ which were conducted during the second week, and included the efficiency of both, true and apparent absorption of minerals.

Treatments and diets. The treatments consisted of increasing amounts of supplementary $\mathrm{P}$ (dicalcium phosphate with $16 \% \mathrm{P}$ ) in the diet $(0,2,4$ and $6 \mathrm{~g} /$ day $)$. The four diets prepared were isocaloric and isoproteic (Table 1). The basal diet (treatment without supplement) was formulated to meet the nutritional requirements of the NRC recommendations $(6,7)$, and the others were formulated to provide higher $\mathrm{P}$ and $\mathrm{Ca}(>0.2 \% \mathrm{P}$ in $\mathrm{DM})$ levels, than those required. The Ca: $P$ ratio was similar in all treatments with supplementary P (Table 1 ).

The diet, consisting of concentrate $(300 \mathrm{~g} /$ day), added with phosphate, and "coast-cross" (Cynodum dactylon L. pers) hay, offered daily in separate feeders. The concentrate was offered in the morning and hay was supplied twice daily ( 8 am and $5 \mathrm{pm}$ ), to allow $10 \%$ orts. Food and water intake for each animal was determined daily, considering the difference between supply and rejected feed. 
Table 1. Constitution and chemical composition of diets in different amounts of supplementary phosphorus $(P)$.

\begin{tabular}{lcccc}
\hline \multirow{2}{*}{\multicolumn{1}{c}{ Ingredient ${ }^{1}$, \% }} & $\mathbf{0}$ & $\mathbf{2}$ & $\mathbf{4}$ & $\mathbf{6}$ \\
\cline { 2 - 5 } Coast Cross hay & 71.6 & 70.6 & 69.7 & 68.8 \\
Cassava meal & 18.8 & 18.5 & 18.3 & 18.1 \\
Soybean meal & 5.7 & 5.6 & 5.6 & 5.5 \\
Molasses & 1.2 & 1.2 & 1.2 & 1.2 \\
Urea & 1.7 & 1.7 & 1.7 & 1.6 \\
Dicalcium phosphate & 0 & 1.3 & 2.6 & 3.9 \\
Mineral moisture* & 1.0 & 1.0 & 1.0 & 1.0 \\
Composition ${ }^{2}, \%$ & & & & \\
\hline TDN & 50.9 & 50.3 & 49.6 & 49.0 \\
CP & 11.9 & 11.7 & 11.5 & 11.4 \\
EE & 1.7 & 1.6 & 1.6 & 1.6 \\
MM & 7.2 & 8.5 & 9.7 & 10.8 \\
NDF & 59.3 & 58.6 & 57.8 & 57.0 \\
ADF & 32.6 & 32.2 & 31.7 & 31.3 \\
P & 0.16 & 0.37 & 0.58 & 0.79 \\
Ca & 0.35 & 0.65 & 0.96 & 1.25 \\
\hline
\end{tabular}

${ }^{1}$ Wet basis; ${ }^{2}$ Dry basis; TDN=91.023 - 0.572(NDF,\%) (7). ${ }^{*}$ Composition: $\mathrm{Cl}, 219 \mathrm{mg} / \mathrm{g} ; \mathrm{Na}, 145 \mathrm{mg} / \mathrm{g} ; \mathrm{S}, 70 \mathrm{mg} / \mathrm{g} ; \mathrm{Mg}, 10 \mathrm{mg} / \mathrm{g}$; $\mathrm{Zn}, 4.6 \mathrm{mg} / \mathrm{g} ; \mathrm{Mn}, 1.1 \mathrm{mg} / \mathrm{g} ; \mathrm{Fe}, 0.50 \mathrm{mg} / \mathrm{g} ; \mathrm{Cu}, 0.30 \mathrm{mg} / \mathrm{g} ; \mathrm{I}, 80 \mathrm{mg} /$ $\mathrm{kg}$; Co, $40 \mathrm{mg} / \mathrm{kg}$; e Se, $15 \mathrm{mg} / \mathrm{kg}$.

Digestibility and laboratory methods. To determine the apparent digestibility of nutrients, the method of total feces collection was used, using the data from samples taken from the second until the seventh day, during the first week in the cages. The feces produced daily were collected in plastic bags adapted to the cages. After removing the bags, the feces were weighed. Later, after homogenization, $10 \%$ of the produced quantity was separated and dried at $60^{\circ} \mathrm{C}$ during 48 hours. Finally, a composite sample was formed for each animal, which was ground and stored for further analysis.

The urine excreted daily was collected in plastic buckets containing $100 \mathrm{ml}$ of $10 \%$ sulfuric acid. Aliquots corresponding to $10 \%$ of the daily total were stored in plastic vials and stored at $-20^{\circ} \mathrm{C}$ for further analysis.

Supplied feed, daily hay orts and produced feces, dry matter (DM), mineral matter (MM), organic matter (OM), ether extract (EE) and crude protein (CP) were determined (8) from samples of the feed ingredients. Neutral detergent fiber (NDF) and acid detergent fiber (ADF) were determined using amylase and correcting for ash (9).

The hay samples (offered and orts) and concentrate were initially incinerated $\left(500^{\circ} \mathrm{C}\right)$, during eight hours, for determination of inorganic
P. After $\mathrm{HCl}$ digestion, samples were filtered and the volume was completed to $100 \mathrm{ml}$. Subsequently, the determination of $P$ was performed in the sample using a spectrophotometer, through the colorimetric method vanadate-molybdate (10). The Ca content was determined by atomic absorption spectrometry (11).

To determine the $P$ content in dicalcium phosphate, $1 \mathrm{~g}$ of sample was digested by adding $30 \mathrm{ml}$ nitric acid and $5 \mathrm{ml}$ of hydrochloric acid for later determination of $\mathrm{P}$ through the vanadatemolybdate method (11).

The coefficients of apparent digestibility of DM, OM, CP, MM, NDF and ADF were evaluated. In the specific case of $P$ and $C a$, apparent (AAC) and true (TAC) absorption coefficients were calculated and compared. The AAC was calculated as follows:

$A A C(P$ or $C a)=($ mineral intake - excreted mineral)/mineral intake

To determine TAC of $\mathrm{P}$ and $\mathrm{Ca}$, it was necessary to calculate endogenous feces loss for both elements, as indicated below.

$\mathrm{N}, \mathrm{P}$ and Ca retention were also calculated:

Retention $=$ mineral intake $-($ mineral in feces + mineral in urine)

The urine produced daily, with $100 \mathrm{ml}$ of $10 \%$ $\mathrm{H}_{2} \mathrm{SO}_{4}$ was measured, and $10 \%$ of it was collected for $\mathrm{N}$ content determination (8).

On the seventh day that the animals were in cages, a radioactive solution of ${ }^{32} \mathrm{P}\left(\mathrm{Na}_{2} \mathrm{H}^{32} \mathrm{PO}_{4}\right)$, obtained from the Instituto de Pesquisas Energéticas e Nucleares (Institute of Energy and Nuclear Research), was prepared. The carrier free, radiolabeled sodium phosphate was diluted in $11.2 \mathrm{ml}$ of $0.85 \%$ sodium chloride sterile solution, by preparing the solution to be injected into the animals. In that order, each animal received $7.4 \mathrm{MBq}$ of ${ }^{32} \mathrm{P}$ in $0.5 \mathrm{ml}$ of solution. Simultaneously, following the same methodology, a solution of ${ }^{45} \mathrm{CaCl}$ was also prepared (7.7 MBq of ${ }^{45} \mathrm{Ca}$ per dose).

On the eighth day, in the morning, the prepared doses of ${ }^{32} \mathrm{P}$ and ${ }^{45} \mathrm{Ca}$ were injected separately into the animals through the right jugular vein. Blood samples were collected five minutes after injection, and then, every 24 hours over seven days. The blood was centrifuged at $1100 \times g$ for ten minutes, at $20^{\circ} \mathrm{C}$, to separate the plasma. Samples of $1 \mathrm{ml}$ of plasma were mixed with $9 \mathrm{ml}$ of trichloroacetic acid (10\%) for protein 
precipitation. After ten minutes, the material was centrifuged at $1100 \times g$ and the supernatant was separated for $\mathrm{P}$ analysis through colorimetry (12) and $\mathrm{Ca}$ analysis through atomic absorption spectrophotometry (11).

From the $24^{\text {th }}$ hour after the injection of radioisotopes, up to eight days, feces and urine produced daily, were collected and formed samples corresponding to $10 \%$ of the total. An aliquot of $1 \mathrm{~g}$ of feces was placed in a furnace for drying and then burned in the oven $\left(500^{\circ} \mathrm{C}\right)$. Later, the digestion of ash with $5 \mathrm{ml}$ of concentrated hydrochloric acid and the reading of $\mathrm{P}$ by colorimetry (10) and $\mathrm{Ca}$ by atomic absorption spectrophotometry were done (11). The contents of inorganic P (12) and $\mathrm{Ca}$ (11) in urine were determined.

The radioactivity detection for $\mathrm{P}$ and $\mathrm{Ca}$, from plasma and feces samples, was made by Cerenkov effect, using the liquid scintillation method (13) in a liquid scintillation spectrophotometer (Beckman LS 5000 - TA).

The $P$ and $C a$ percentages from endogenous origins in the feces were calculated using the isotope dilution technique (14), which considers the specific activity in feces (SAF) and plasma (SAP):

Endogenous fecal P or Ca $(\%)=($ SAF/SAP $) \times 100$ $\mathrm{SAF}=[($ Sample activity/Standard activity $)] /(\mathrm{mg}$ of mineral/g feces)

SAP $=[($ Sample activity/Standard activity $)] /(\mathrm{mg}$ of mineral/ml plasma)

Endogenous fecal loss $(\mathrm{g} / \mathrm{d})$ - excreted mineral (g) $\times \%$ endogenous mineral

The value of endogenous $\mathrm{P}$ and $\mathrm{Ca}$ in the feces was used to calculate the true absorption coefficient (TAC):

TAC $(\mathrm{P}$ or $\mathrm{Ca})=$ [mineral intake $-($ mineral in feces - endogenous mineral in feces)]/ mineral intake

Ethics Committee. After seven days of collection, the lambs were slaughtered according to the procedures of the Ethics Committee on Animal Experimentation of CENA. The carcasses were taken to a warehouse built under the supervision of the Radiological Protection Service of CENA.

Experimental design and statistical analysis. A randomized block design was used. Variance analysis was performed considering the effect of the following sources of variation: block (two groups), level of supplemental $\mathrm{P}$ and error. In the model, the sum of squares for the $P$ content factor in the diet was divided to test linear, quadratic and cubic effects, with one degree of freedom in each contrast. Correlation analysis was performed. In the case of significant effect of $P$ level, regression was performed, using the absolute values of the average intake for each level of supplementation. The comparison of true and apparent absorption coefficient values of $P$ was performed using the $t$ test $(p<0.05)$. The statistical analysis of the data was performed using the GLM functions and correlation of SPSS version 12 software for Windows. In the result tables, in some cases, the $P$ value of cubic contrast was not shown as it was not significant $(p>0.05)$.

\section{RESULTS}

The increase in supplementation levels with dicalcium phosphate resulted in an increase $(p<0.001)$ in $P$ intake (Table 2$)$.

Table 2. Means of intake (DM, $P, C a)$, apparent absorption coefficient (AAC) of nutrients, true absorption coefficient (TAC) of $\mathrm{P}$ and $\mathrm{Ca}$, and retention $(\mathrm{N}, \mathrm{P}, \mathrm{Ca})$ in lambs supplemented with different amounts of $P$.

\begin{tabular}{|c|c|c|c|c|c|c|c|}
\hline \multirow{2}{*}{ Variables $^{1}$} & \multicolumn{4}{|c|}{ Supplementary P (g/d) } & \multirow{2}{*}{ ME } & \multirow{2}{*}{ C } & \multirow{2}{*}{$\mathbf{P}$} \\
\hline & $\mathbf{0}$ & 2 & 4 & 6 & & & \\
\hline$P$ intake $(g / d)$ & 1.47 & 3.53 & 5.52 & 7.47 & 0.02 & $\mathrm{~L}$ & $* * *$ \\
\hline Ca intake $(\mathrm{g} / \mathrm{d})$ & 3.75 & 7.19 & 10.56 & 13.64 & 0.05 & $\mathrm{~L}$ & $* * *$ \\
\hline $\begin{array}{l}\text { P excreted } \\
(\mathrm{g} / \mathrm{d})\end{array}$ & 1.10 & 3.19 & 4.47 & 6.90 & 0.115 & $\mathrm{~L}$ & $* * *$ \\
\hline $\begin{array}{l}\text { Ca excreted } \\
\text { (g/d) }\end{array}$ & 2.49 & 5.76 & 7.76 & 7.53 & 0.251 & $\mathrm{~L}$ & $* * *$ \\
\hline $\begin{array}{l}\text { DM intake } \\
(\mathrm{kg} / \mathrm{d})\end{array}$ & 0.926 & 0.961 & 0.985 & 0.90 & 0.024 & - & ns \\
\hline AAC of DM & 0.59 & 0.61 & 0.57 & 0.57 & 0.005 & - & ns \\
\hline$A A C$ of $C P$ & 0.64 & 0.65 & 0.62 & 0.64 & 0.006 & - & ns \\
\hline AAC of OM & 0.61 & 0.63 & 0.59 & 0.61 & 0.006 & - & ns \\
\hline$A A C$ of $M M$ & 0.27 & 0.12 & -0.11 & -0.36 & 0.012 & $L$ & $* * *$ \\
\hline AAC of NDF & 0.46 & 0.49 & 0.47 & 0.51 & 0.007 & - & ns \\
\hline$A A C$ of $A D F$ & 0.45 & 0.49 & 0.44 & 0.43 & 0.014 & - & ns \\
\hline AAC of $P$ & 0.24 & 0.01 & 0.22 & 0.12 & 0.026 & - & ns \\
\hline $\mathrm{AAC}$ of $\mathrm{Ca}$ & 0.34 & 0.20 & 0.26 & 0.11 & 0.025 & - & ns \\
\hline TAC of $P$ & 0.66 & 0.55 & 0.64 & 0.45 & 0.027 & $\mathrm{C}$ & $*$ \\
\hline TAC of $\mathrm{Ca}$ & 0.55 & 0.38 & 0.42 & 0.26 & 0.027 & $\mathrm{~L}$ & $* *$ \\
\hline$N$ retained $(\mathrm{g} / \mathrm{d})$ & 1.63 & 3.34 & 2.88 & 3.34 & 1.1 & - & ns \\
\hline$P$ retained $(g / d)$ & 0.37 & 0.34 & 1.05 & 0.57 & 0.14 & - & ns \\
\hline $\begin{array}{l}\text { Ca retained } \\
(\mathrm{g} / \mathrm{d})\end{array}$ & 1.16 & 1.28 & 2.70 & 1.44 & 0.252 & - & ns \\
\hline $\begin{array}{l}\text { Water intake } \\
(\mathrm{I} / \mathrm{d})\end{array}$ & 2.48 & 2.63 & 2.64 & 2.76 & 0.07 & - & ns \\
\hline
\end{tabular}

${ }^{1} \mathrm{DM}$ (Dry matter); CP(Crude protein); OM(organic matter); MM(Minera matter); NDF(Neutral detergent fiber) and ADF(Acid detergent fiber). ME:Mean standard error

$\mathrm{C}:$ Cont $=\mathrm{L}$ :(Linear), Q:(quadratic) and $\mathrm{C}:($ Cubic) contrast

P value of contrast: ${ }^{*}(p<0.05) ;{ }^{* *}(p<0.01) ;{ }^{* * *}(p<0.001)$ 
The regression models that explain the variables with significant contrast are shown in table 3 .

Table 3. Prediction equations of differents variables of $\mathrm{Ca}$ and $\mathrm{P}$ and digestibility in lambs as $\mathrm{a}$ function of $P$ intake

\begin{tabular}{|c|c|c|}
\hline Variable & Regression & $\mathbf{R}^{2}$ \\
\hline Ca intake $(\mathrm{g} / \mathrm{d})$ & Ca Intake $=1.145+1.624 \times \mathrm{P}$ intake & 0.99 \\
\hline P excreted $(\mathrm{g} / \mathrm{d})$ & $\begin{array}{c}P \text { excreted }(\mathrm{g} / \mathrm{d})=-0.21+0.91 \\
\times P \text { intake }\end{array}$ & 0.91 \\
\hline Ca excreted $(\mathrm{g} / \mathrm{d})$ & $\begin{array}{c}\text { Ca excreted }(\mathrm{g} / \mathrm{d})=0.586+1.362 \\
\times P \text { intake }\end{array}$ & 0.89 \\
\hline AAC of MM & $\mathrm{AAC}$ of $\mathrm{MM}=0.46-0.108 \times \mathrm{P}$ intake & 0.84 \\
\hline TAC of $P$ & $\begin{array}{l}\text { TAC of } P=2.16-(1.95 \times P \text { intake })+ \\
0.55 \times(P \text { intake })^{2}-0.04 \times(P \text { intake })^{3}\end{array}$ & 0.38 \\
\hline TAC of $\mathrm{Ca}$ & TAC of $\mathrm{Ca}=0.559-0.03 \times \mathrm{P}$ intake & 0.26 \\
\hline
\end{tabular}

There were no effects $(p>0.05)$ in $P$ intake from DM intake (Table 2), which had an average value of $0.943 \mathrm{~kg} / \mathrm{d}(2.8 \% \mathrm{BW})$. The concentrate supplied daily ( $300 \mathrm{~g} /$ day), which was added with the phosphate, did not present orts during the experimental period, indicating that the mineral source was consumed completely in all animals.

The apparent digestibility coefficients of DM, OM, CP, NDF and ADF (Table 2), which showed average values of $0.59 \pm 0.02,0.61 \pm 0.03,0.64 \pm 0.03$, $0.48 \pm 0.04$ and $0.45 \pm 0.07$, respectively, were not affected by the treatments $(p>0.05)$. However, the digestibility of the mineral fraction in the diet, which was affected by treatments $(p<0.001)$, had a $56 \%$ decrease when the $P$ intake went from 1.47 to $3.53 \mathrm{~g} / \mathrm{d}$, and $69 \%$ between intake levels of 5.52 and $7.47 \mathrm{~g} / \mathrm{d}$.

Water intake (Table 2) was not affected by treatments $(p=0.665)$. The relationship between water and DM intake was 2.7:1 in the first three levels of supplementation. On the highest level of supplementation, $(6 \mathrm{~g} / \mathrm{d})$ the ratio was $3: 1$.

The apparent absorption coefficient (AAC) of $P$ was not affected by treatments $(p>0.05)$, different from that observed for the coefficient of true absorption (TAC), which was linearly influenced $(p=0.015)$ by the increase in $P$ intake (Table 2).

The relationship between $P$ intake and TAC of the mineral can be observed in table 3 . The most accentuated decrease $(17 \%)$ in the efficiency of $P$ absorption occurred after ingestion of $5 \mathrm{~g} / \mathrm{d}$ of $P$. Between the lowest intake level and intake of $5 \mathrm{~g} / \mathrm{d}$ of $\mathrm{P}$ the decrease was $9 \%$.
The $\mathrm{P}$ content in plasma, which was influenced by treatments $(6.66,7.92,8.78$ and $9.02 \mathrm{mg} / 100 \mathrm{ml}$ in the levels of $0,2,4$ and $6 \mathrm{~g} / \mathrm{d}$ of supplementary $\mathrm{P})$, was correlated $(0.51, \mathrm{p}<0.01)$ with the true amount of $\mathrm{P}$ absorbed. A significant correlation $(0.51, \mathrm{p}<0.001)$ was also observed between $P$ content in plasma and $\mathrm{P}$ amount present in feces.

Despite the correlation $(0.55 ; \mathrm{p}<0.05)$ between $A A C$ and TAC values for $P$ (Figure 1 ), they were different $(p<0.001)$. The average values were 0.17 and 0.56 for AAC and TAC, respectively.

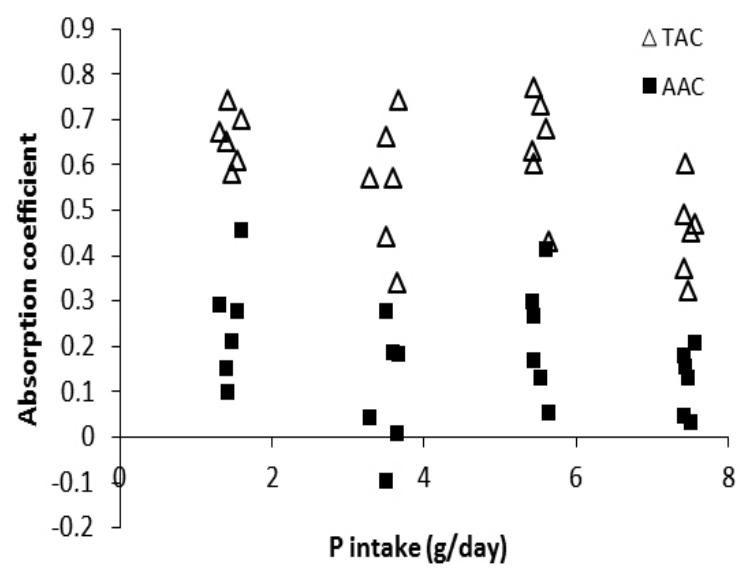

Figure 1. Observed values of true absorption coefficients (TAC) and apparent absorption coefficient (AAC) of $P$ in lambs supplemented with different amounts of $P$.

$P$ retention was not affected $(p>0.05)$ by the increase in $P$ intake (Table 2) and presented positive values.

Similar results were observed in $\mathrm{Ca}$, in relation to AAC and TAC values, where the average values of AAC and TAC were, also, different $(p<0.001)$, despite the correlation $(0.56 ; p=0.005)$ between them (Figure 2).

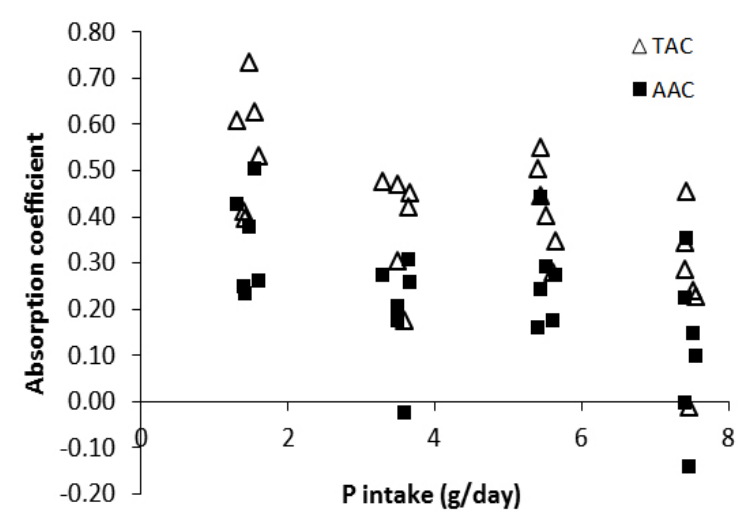

Figure 2. Observed values of true absorption coefficients (TAC) and apparent absorption coefficient (AAC) of $\mathrm{Ca}$ in lambs supplemented with different amounts of $P$. 
The efficiency of Ca absorption decreased linearly $(p=0.01)$ as the level of $P$ and Ca increased in the diet (Table 3); with a decrease of 0.03 points in the absorption efficiency for each $1 \mathrm{~g}$ of ingested $P$.

The retention of $\mathrm{N}, \mathrm{P}$ and $\mathrm{Ca}$ (Table 2 ) were also not affected ( $p>0.05)$ by the $P$ content in the diet, and its values were not correlated $(p>0.05)$. The retention values were positive in all treatments.

\section{DISCUSSION}

In relation to the apparent digestibility of the mineral fraction (MM) the fact that this coefficient of digestibility is apparent should be considered, and therefore, it does not consider the endogenous loss of minerals in feces, so it is possible to obtain negative values.

Dry matter digestibility was not affected in this study $(p>0.05)$, which coincides with other studies that only detected a decrease when phosphorus deficiency was severe in goats (15).

Although there are not many studies that evaluate the digestibility of nutrients when providing different amounts of $P$, there is evidence that indicates that organic matter (OM) digestibility is usually not affected, if there is no $P$ deficit $(15,16)$. On the contrary to what happened in the present study, the authors found that the coefficient of absorption of the NDF fraction ( $50 \%$ of the diet) in adult sheep $(38-43 \mathrm{~kg}$ ) was affected $(p<0.05)$ by variations in the $P$ levels (up to $8 \mathrm{~g} \mathrm{P} /$ day). The coefficients observed, were between 0.47 and 0.49 , similar to those found in this study (between 0.46 and 0.51 ).

The digestibility coefficient of OM, with an average of $0.61 \pm 0.028$, was similar to that found by Coneglian et al (16) in steers, with an average value of 0.66 .

The lower efficiency of $\mathrm{P}$ absorption corresponded to a higher $\mathrm{P}$ intake, indicating that the absorption tends to decrease with the increase of $P$ in the diet.

The decrease in true absorption efficiency could indicate that the two pathways that determine $P$ absorption in the intestine (transcellular and paracellular) were being affected.

Results obtained for $\mathrm{P}$ plasma levels suggest the presence of homeostatic mechanisms. Considering the results of Williams and Luca (17), the effect of $1.25-(\mathrm{OH})_{2} \mathrm{D}_{3}$ disappeared in the presence of high levels of phosphate in the intestine, it is possible that the increase in plasmatic concentration of $\mathrm{P}$ was the main cause for the decreased levels of $1.25-(\mathrm{OH})_{2} \mathrm{D}_{3}$ and consequently, for the decrease in the efficiency of $\mathrm{P}$ absorption by the intestine. Muscher et al (18) indicated that other substances, in addition to $1.25-(\mathrm{OH})_{2} \mathrm{D}_{3}$ could be participating in the process of $\mathrm{P}$ absorption. However, the variables in this study do not indicate accurately the mechanisms that negatively influenced the absorption of $P$. It was evident that the AAC significantly underestimated the real efficiency of $\mathrm{P}$ absorption in the diet (Figure 2), as indicated by Bravo et al (3). Thus, the apparent absorption coefficient does not appear to be a good indicator to make conclusions about availability of $P$ in the diet.

The values for TAC of $P$ observed in this study ( 0.45 to 0.66 ) were lower than the value set by the CSIRO (19) of 0.70 for all physiological phases. The NRC (6) recommends a coefficient of 0.60 to calculate the dietary requirement of $P$ in sheep during maintenance, lactation and pregnancy, and of 0.72 in growing sheep. According to this recommendation, except for the coefficient of 0.45 in the diet with the highest content of $\mathrm{P}$, the values were closer to those indicated for maintenance.

Portillo et al (14), using the isotopic dilution technique with ${ }^{32} \mathrm{P}$, found a higher TAC than those found in this study, for lambs with $22 \mathrm{~kg}$ BW. The lowest coefficient (diet with no addition of phosphate) was 0.58 . In other diets, the coefficients were between 0.67 and 0.72 . The physiological stage could be one of the causes of the differences between the studies. Underwood and Suttle (20) had already shown that young animals are more efficient in $\mathrm{P}$ absorption than mature animals. Therefore, it is controversial that some committees consider constant coefficients of absorption for all animal categories to define the amount of $P$ to be ingested.

Using the equation described by NRC (6) and CSIRO (19) to determine the $P$ ingestion, the consumption for these animals should be around $1.6 \mathrm{~g} / \mathrm{d}$. Considering the efficiency of $\mathrm{P}$ absorption in the lower intake level could indicate that this diet was slightly deficient in the element.

In relation to $P$ Balance, Portillo et al (14), evaluated the intake levels of $P$, in Santa Ines lambs with $22 \mathrm{~kg} \mathrm{BW}$, and observed that for the lower intake levels ( 0 and $1.5 \mathrm{~g}$ of supplemental $P$ ) retention was negative, and the for the higher intake levels ( 3 and $4.5 \mathrm{~g}$ of supplemental P) it was positive, with a linear increase in $P$ retention with increasing intake. Considering these results, 
it is possible to conclude that there is a difference in relation to $P$ balance between individuals in different growth stages. The authors explained the linear increase in $P$ retention due to the requirements for growing animals at that specific age. Regarding the coefficients of absorption of $\mathrm{Ca}$, a similar situation occurred to that of $\mathrm{P}$.

Pfeffer et al (21) observed that in most studies that used $\mathrm{P}$ and $\mathrm{Ca}$ isotopes simultaneously, the values for TAC were higher for $P$ than for Ca. Analyzing how each mineral was affected by the increased intake, it is clear that the mobilization of these minerals through the intestinal epithelium was not fully linked, because the trans-membrane transport systems were differently affected by the hormones involved in the homeostatic processes (17).

A constant value of 0.68 for the coefficient of absorption of $\mathrm{Ca}$, for cattle and sheep of all ages, is considered by CSIRO (19) to calculate the dietary requirement of $\mathrm{Ca}$. The NRC (6) adopted the same previous value (0.68) for growing sheep, regardless of age, and a coefficient of 0.40 for animals at a maintenance level. The TAC value for $C a$ obtained at the lowest $P$ level in the diet $(0.55)$ is closer to the one indicated by Roque et al (22) of 0.62 in lambs supplemented with limestone.
If we consider the indications of other authors (23-27) in relation to the coefficients of absorption of $\mathrm{Ca}$ and $\mathrm{P}$, there are still aspects that could cause differences in the determination of dietary requirements.

This indicates that in the case of $\mathrm{P}$ and $\mathrm{Ca}$, the excretion of these minerals increased as the intake of the elements increased, which partially explains what happened to the retention of $P$ and $\mathrm{Ca}$, which showed no changes between treatments. Absence of correlation between $\mathrm{N}$, $\mathrm{P}$ and $\mathrm{Ca}$ balance values indicate that there was no link between the factors that determined the retention of these elements, as reported by Block et al (4).

In conclusion, the increase in $\mathrm{P}$ intake does not affect the efficiency in which the components of the organic fraction of the diet were absorbed in the gastrointestinal tract. But, in the case of phosphorus, when the intake exceeds five grams a day, the coefficient of real absorption decreases by $17 \%$. Under the conditions of this study, the coefficient of apparent absorption for both $P$ and $\mathrm{Ca}$ is not a reliable parameter to determine the efficiency in which dietary $\mathrm{Ca}$ and $\mathrm{P}$ were absorbed. Therefore, when it is not feasible to use markers such as ${ }^{32} \mathrm{P}$ or ${ }^{45} \mathrm{Ca}$, either balance or retention of these minerals, should be considered to infer variations in dietary $\mathrm{Ca}$ and $\mathrm{P}$.

\section{REFERENCES}

1. Borges ES, da Silva Filho JC, Roque NC, Olalquiaga JP, Vitti DMSS, Patiño RM. Dinâmica do fósforo em ovinos alimentados com dietas contendo diversos níveis deste mineral. $\mathrm{R}$ Bras Zootec 2008; 37:1679-1684.

2. Owens FN, Sapienza DA, Hassen AT. Effect of nutrient composition of feeds on digestibility of organic matter by cattle: A review. J Anim Sci 2010; 88 Supl 1:E151-E169.

3. Bravo D, Sauvant D, Bogaert C, Meschy F. Quantitative aspects of phosphorus absorption in ruminants, part. II. Rep Nut Dev 2003; 43:271-284.

4. Block HC, Erickson GE, Klopfenstein TJ. Review: re-evaluation of phosphorus requirements and phosphorus retention of feedlot cattle. Prof Anim Sci 2004; 20:319-329.
5. Dove H, Charmley E. Relationships between phosphorus intake, plasma phosphorus and fecal and urinary phosphorus excretion in young sheep. Anim Prod 2004; 25:37-40.

6. National Research Council - NRC. Nutrient requirements of small ruminants: sheep, goats, cervids, and new word camelids. Washington D.C: National Academic Press; 2007.

7. Cappelle ER, Valadares Filho SC, Silva JFC, Cecon PR. Estimativas do valor energético a partir de características químicas e bromatológicas dos alimentos. Rev Bras Zoot 2001; 30:1837-1856.

8. Silva DJ, Queiroz AC. Análise de alimentos: Métodos químicos e biológicos. 3ra ed. Viçosa, Brasil: Editora UFV; 2002. 
9. Campos FP de, Nussio CMB, Nussio LG. Métodos de análise de alimentos. 1ra ed. Piracicaba, Brasil: FEALQ; 2004.

10. Sarruge JR, Haag HP. Análises químicas em plantas. Piracicaba, Brasil: ESALQ/USP; 1974.

11. Zagatto EAG, Krug FJ, Bergamin Filho $\mathrm{H}$. Jorgenson SS, Reis Bf. Merging zones in flow injection analysis. Part 2. Determination of calcium, magnesium and potassium in plant material by flow injection atomic absorption and flame emission spectrometry. Anal Chim Acta 1979; 104:279-284.

12. Fiske $\mathrm{CH}$, Subarrow $\mathrm{Y}$. The colorimetric determination of phosphorus. J Biol Chem $1925 ; 66: 375-400$.

13. Nascimento Filho VF. Utilização do efeito Cerenkov na detecção de radionuclideos emissores de radiações beta. Piracicaba: Centro de Energia Nuclear na Agricultura; 1977.

14. Portilho FP, Vitti DMSS, Abdalla AL, McManus CM, Rezende MJM, Louvandini H. Minimum phosphorus requirement for Santa Inês lambs reared under tropical conditions. Small Rum Res 2006; 63:170-176.

15. Yan Q, Tang S, Bamikole NA, Han X, Zhou C, Wan M, Sun Z, Tan Z. Influence of dietary phosphorus variation on nutrient digestion, fecal endogenous phosphorus output and plasma parameters of goats. Livestock Sci 2011; 142:63-69.

16. Coneglian CM, Branco AF, Guimarães KC, Mano DS, Barreto JC, Fávaro BR. Replacement of dicalcium phosphate by rock phosphate in cattle diets: nutrient digestibility, plasma parameters, ruminal fermentation and microbial synthesis efficiency. R Bras Zootec 2010; 39:815-823.

17. Williams KB, Luca HF. Characterization of intestinal phosphate absorption using a model in vivo method. Am J Physiol Endocrinol Metab 2007; 292:E1917-E1921.

18. Muscher A, Hattendorf J, Pfeffer E, Breves G, Huber K. Hormonal regulation of phosphate homeostasis in goats during transition to rumination. J Comp Physiol B Biochem, Syst Environ Physiol 2008; 178:585-596.
19. Commonwealth Scientific and Industrial Research Organization - CSIRO. Nutrient requirements of domesticated ruminants. Collingwood, Australia: CSIRO Publishing; 2007.

20. Underwood EJ, Suttle NF. Los minerales en la nutrición del ganado. Zaragoza, España: Editorial Acribia; 2003.

21. Pfeffer E, Beede DK, Valk H. Phosphorus metabolism in ruminants and requirements of cattle. In: Pfeffer E, Hristov A, editors. Nitrogen and phosphorus nutrition of cattle: reducing the environmental impact of cattle operations. London: CABI Publishing; 2005.

22. Roque AP, Dias RS, Vitti DMSS, Bueno IC, Da Cunha EA, Santos LE, Bueno MS. True digestibility of calcium from sources used in finishing Lamb diets. Small Rum Res 2007; $71: 243-249$.

23. Dias RS, Kebreab E, Vitti DMSS, Roque AP, Bueno ICS, France J. A revised model for studying phosphorus and calcium kinetics in growing sheep. J Anim Sci 2006; 84:2787-2794.

24. Knowlton KF, Beede DK, Kebreab E. Phosphorus and calcium requirements of ruminants. In: Vitti DMSS, Kebreab E, editors. Phosphorus and calcium utilization and requirements in farms animals. London: CABI Publishing; 2010.

25. Dias RS, Kebreab E, Vitti DMSS, Portilho FP, Louvanidini $\mathrm{H}$, France J. Phosphorus kinetics in lambs fed different levels of dicalcium phosphate. J Agric Sci 2007;145:509-516.

26. Vittti DMSS, da Silva Flilho JC. Isotope dilution technique. In: Vitti DMSS, Kebreab $\mathrm{E}$, editors. Phosphorus and calcium utilization and requirements in farms animals. London: CABI Publishing; 2010.

27. Buendía G, Mendoza G, Pinos-Rodríguez JM, González-Muñoz S, Aranda E, Miranda $L$, Melgoza L. Influence of supplemental phytase on growth performance, digestión and phosphorus balance of lambs fed sorghum-based diets. Ital J Anim Sci 2010; 9:186-189 